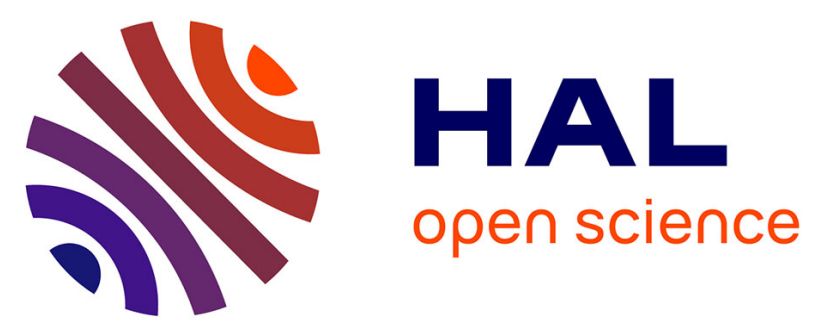

\title{
A novel, small molecule inhibitor of Hsc70/Hsp70 potentiates Hsp90 inhibitor induced apoptosis in HCT116 colon carcinoma cells
}

\author{
Andrew J. Massey, Douglas S. Williamson, Helen Browne, James B. Murray, \\ Pawel Dokurno, Terry Shaw, Alba T. Macias, Zoe Daniels, Stephanie \\ Geoffroy, Melanie Dopson, et al.
}

\section{To cite this version:}

Andrew J. Massey, Douglas S. Williamson, Helen Browne, James B. Murray, Pawel Dokurno, et al.. A novel, small molecule inhibitor of Hsc70/Hsp70 potentiates Hsp90 inhibitor induced apoptosis in HCT116 colon carcinoma cells. Cancer Chemotherapy and Pharmacology, 2009, 66 (3), pp.535-545. 10.1007/s00280-009-1194-3 . hal-00552481

\section{HAL Id: hal-00552481 \\ https://hal.science/hal-00552481}

Submitted on 6 Jan 2011

HAL is a multi-disciplinary open access archive for the deposit and dissemination of scientific research documents, whether they are published or not. The documents may come from teaching and research institutions in France or abroad, or from public or private research centers.
L'archive ouverte pluridisciplinaire HAL, est destinée au dépôt et à la diffusion de documents scientifiques de niveau recherche, publiés ou non, émanant des établissements d'enseignement et de recherche français ou étrangers, des laboratoires publics ou privés. 


\title{
A novel, small molecule inhibitor of $\mathrm{Hsc70/Hsp70}$ potentiates Hsp90 inhibitor induced apoptosis in HCT116 colon carcinoma cells
}

\author{
Andrew J. Massey • Douglas S. Williamson · Helen Browne • James B. Murray • Pawel Dokurno • \\ Terry Shaw $\cdot$ Alba T. Macias $\cdot$ Zoe Daniels $\cdot$ Stephanie Geoffroy $\cdot$ Melanie Dopson $\cdot$ Paul Lavan \\ Natalia Matassova · Geraint L. Francis · Christopher J. Graham • Rachel Parsons • Yikang Wang • \\ Antony Padfield $\cdot$ Mike Comer $\cdot$ Martin J. Drysdale $\cdot$ Mike Wood
}

Received: 15 September 2009/Accepted: 24 November 2009/Published online: 13 December 2009

(C) Springer-Verlag 2009

\begin{abstract}
Purpose The anti-apoptotic function of the $70 \mathrm{kDa}$ family of heat shock proteins and their role in cancer is well documented. Dual targeting of Hsc70 and Hsp70 with siRNA induces proteasome-dependent degradation of Hsp90 client proteins and extensive tumor specific apoptosis as well as the potentiation of tumor cell apoptosis following pharmacological Hsp90 inhibition.

Methods We have previously described the discovery and synthesis of novel adenosine-derived inhibitors of the $70 \mathrm{kDa}$ family of heat shock proteins; the first inhibitors described to target the ATPase binding domain. The in vitro activity of VER-155008 was evaluated in HCT116, HT29, BT474 and MDA-MB-468 carcinoma cell lines. Cell proliferation, cell apoptosis and caspase $3 / 7$ activity was determined for VER-155008 in the absence or presence of small molecule Hsp90 inhibitors.

Results VER-155008 inhibited the proliferation of human breast and colon cancer cell lines with $\mathrm{GI}_{50} \mathrm{~s}$ in the range 5.3-14.4 $\mu \mathrm{M}$, and induced Hsp90 client protein degradation in both HCT116 and BT474 cells. As a single agent, VER-155008 induced caspase-3/7 dependent apoptosis in BT474 cells and non-caspase dependent cell death in HCT116 cells. VER-155008 potentiated the apoptotic potential of a small molecule Hsp90 inhibitor in HCT116
\end{abstract}

All authors are either present or past employees of Vernalis (R\&D) Ltd.

A. J. Massey $(\bowtie) \cdot$ D. S. Williamson · H. Browne

J. B. Murray - P. Dokurno - T. Shaw - A. T. Macias ·

Z. Daniels · S. Geoffroy · M. Dopson · P. Lavan ·

N. Matassova - G. L. Francis - C. J. Graham - R. Parsons .

Y. Wang · A. Padfield - M. Comer - M. J. Drysdale · M. Wood

Vernalis (R\&D) Ltd, Granta Park, Cambridge CB21 6GB, UK

e-mail: a.massey@vernalis.com but not HT29 or MDA-MB-468 cells. In vivo, VER155008 demonstrated rapid metabolism and clearance, along with tumor levels below the predicted pharmacologically active level.

Conclusion These data suggest that small molecule inhibitors of Hsc70/Hsp70 phenotypically mimic the cellular mode of action of a small molecule Hsp90 inhibitor and can potentiate the apoptotic potential of a small molecule Hsp90 inhibitor in certain cell lines. The factors determining whether or not cells apoptose in response to Hsp90 inhibition or the combination of Hsp90 plus Hsc70/ Hsp70 inhibition remain to be determined.

Keywords Hsc70 - Hsp70 - Hsp90 - Small molecule inhibitor - Apoptosis · Combination studies .

Pharmacokinetics

\section{Introduction}

Heat shock proteins (Hsps) are a highly evolutionarily conserved group of chaperone proteins and include a variety of families defined by their different molecular weights. Of these families, the Hsp70 family represents one of the most conserved groups, with functional counterparts identified from the most primitive bacteria through to humans. At least eight genes have so far been identified and shown to code for Hsp70 family members. The two major cytoplasmic isoforms are $\mathrm{Hsc70}$ and $\mathrm{Hsp} 70$ while mortalin has been found located predominantly in the mitochondria and Grp78 in the endoplasmic reticulum $[1,2]$. These proteins have diverse biological functions including an involvement in nascent protein folding, preventing denatured protein aggregation and modulating the assembly/disassembly of protein complexes [3-5]. 
In non-tumor tissue and in the absence of stress, Hsc70 is generally ubiquitously and abundantly expressed whereas Hsp70 is only found at low levels. Following cellular stress (including the stress of oncogenesis), the expression levels of Hsp70 are increased via transcription factors HSF-1 and HIF-1 activation. In many cancers, this differential expression pattern is lost, with increased basal expression of Hsp70 documented in multiple tumor types [6]. Hsc70 and Hsp70 are members of the actin class of ATPases and exhibit high structural homology, especially within their ATPase domain [7, 8]. The Hsp70 family of chaperones exist in large multi-protein complexes with various co-chaperones including Bag-1, Hip, Hop, Hsp40, HspBP1 and Chip.

The precise role of $\mathrm{Hsp} 70$ in cancer remains unclear. However, these chaperones have been shown to contribute to cancer cell survival via multiple anti-apoptotic functions $[6,9]$ and increased expression of Hsp70 has been implicated in resistance to cytotoxic chemotherapeutics $[10,11]$. Selective knockdown of Hsp70 by both RNAi and antisense results in cell arrest and death in a variety of cancer cell lines [12-15]. Furthermore, localised tumor cell application of Hsp70 antisense expressing adenovirus reduced the growth of orthotopic glioblastoma and breast carcinoma, as well as sub-cutaneous colon cancer xenografts in mice [16].

Hsp70 has been shown to demonstrate a key role in the Hsp90 chaperone machinery. The Hsp90 chaperone machinery maintains the correct conformation, stability and activity of a wide variety of oncogenic client proteins [17]. These clients include many well-known kinases such as Raf-1, Her2, CDK4 and AKT; sex hormone receptors; and other transcription factors. Inhibition of Hsp90 ATPase activity with either the benzoquinone ansamycin 17-AAG or other small molecule inhibitors results in the ubiquitindependent proteasomal degradation of these client proteins [18]. Through its ability to potentially modulate a whole variety of oncogenic processes, Hsp90 is an exciting anti-cancer target [19]. One of the hallmarks of Hsp90 inhibition, along with client protein degradation, is the subsequent up regulation of Hsp70. So universal is this response to Hsp90 inhibition that it is in use as a biomarker for many Hsp90 inhibitor clinical trials [20].

Recent work has demonstrated that targeting both Hsc70 and Hsp70 with siRNA resulted in proteasome-dependent degradation of Hsp90 client proteins, G1 cell-cycle arrest, and extensive tumor-specific apoptosis. Dual depletion of Hsc70 and Hsp70 increased the amount of tumor cell apoptosis following pharmacological Hsp90 inhibition with 17-AAG [21]. Given the plethora of Hsp90 inhibitors in clinical development, and the relative difficulty in obtaining potent, 'drug-like' Hsp70 inhibitors, these siRNA studies suggest that the best use of a small molecule Hsc70/
Hsp70 inhibitor will be in combination with an Hsp90 inhibitor. Such a compound would be predicted to convert cytostatic cellular responses to Hsp90 inhibition into apoptotic cell death. We have therefore utilized a novel, small molecule inhibitor of Hsc70/Hsp70 to further validate this approach.

\section{Materials and methods}

Cell lines, cell culture and materials

All cell lines, unless otherwise stated, were obtained from the American Type Culture Collection and grown in DMEM/10\% FCS with GlutaMAX-I in a humidified atmosphere of $5 \% \mathrm{CO}_{2}$ in air. Cell proliferation was determined using the sulforhodamine B (SRB) assay. VER155008 and VER-82160 were synthesized as previously described [22, 23].

Hsc70, Hsp70, Grp78 and Hsp90 fluorescence polarisation (FP) assay

The activity of VER-155008 was determined against Hsp70 and Hsp90 as previously described [23]. Hsc70 (aa 5-381) and Grp78 (ATPase domain) were cloned and expressed as follows. A PCR fragment of Hsc70 corresponding to amino acids 5-381 was made. The purified PCR fragment was ligated into pCR2.1-TOPO. This was subsequently restriction digested and sub-cloned into the commercial histidine tagged vector pET101 for expression analysis. The ATPase domain of Grp78 was amplified by PCR and cloned into pCR2.1-TOPO. This was subsequently digested and ligated into the glutathione-s-transferase tagged expression vector pGEX-4T-1. The FP assay for Hsc70 and Grp78 was carried out as described for Hsp70 using the same $N^{6}$-(6-amino)hexyl-ATP-5-FAM as the FP probe with the following modifications. For Hsc70, the protein and probe concentrations were $0.3 \mu \mathrm{M}$ and $20 \mathrm{nM}$, respectively with a $30 \mathrm{~min}$ incubation at $22^{\circ} \mathrm{C}$ while for Grp78, the protein and probe concentrations were $2 \mu \mathrm{M}$ and $10 \mathrm{nM}$, respectively with a $2 \mathrm{~h}$ incubation at $22^{\circ} \mathrm{C}$. The $K_{\mathrm{D}}$ for the FAM-ATP probe was $0.24 \mu \mathrm{M}$ for Hsc70 and $2 \mu \mathrm{M}$ for Grp78.

Determination of compound binding to Hsp70 by BiaCore

All experiments were performed on a Biacore T100 at $25^{\circ} \mathrm{C}$ with a flow rate of $30 \mu \mathrm{L} / \mathrm{min}$. The buffer system was identical to that used in the Hsp70 fluorescence polarization assay, with $1 \%$ DMSO and $0.05 \%$ Tween 20. Double His-tagged Hsp70 was immobilised on the surface of a 
NTA sensor chip; approximately 2,000 RU of protein were immobilised. Compounds were injected for $90 \mathrm{~s}$, and the $K_{\mathrm{D}} \mathrm{S}$ were determined from equilibrium binding at $80 \mathrm{~s}$.

\section{Hsp70 ATPase assay}

ATP turnover, and the subsequent generation of ADP, was measured using an ADP Hunter Plus assay kit (DiscoveRx). Reaction mixtures were prepared in half volume, all black non-binding plates (Corning) and contained $250 \mathrm{nM}$ full length, GST-tagged Hsp70, $50 \mu \mathrm{M}$ ATP and increasing concentrations of VER-155008 in the standard kit assay buffer. Reactions were incubated at $30^{\circ} \mathrm{C}$ for $90 \mathrm{~min}$ and then read on a FlexStation 3 (Molecular Devices) with an $E_{\mathrm{x}}$ of $530 \mathrm{~nm}$ and $E_{\mathrm{m}}$ of $590 \mathrm{~nm}$ with six reads per well. Reactions containing no enzyme were set up to monitor the spontaneous hydrolysis of ATP and subtracted from those containing Hsp70.

\section{Refolding of heat denatured luciferase}

This assay was carried out essentially as previously described [24, 25]. In brief, Hsc70/Hsp70 inhibitors were diluted in Rabbit Reticulocyte Lysate (RRL, nuclease treated, Promega) containing $10 \mathrm{mM}$ Tris, $100 \mathrm{mM} \mathrm{KCl}$, $3 \mathrm{mM}$ EDTA, $1 \mathrm{mM}$ DTT and an ATP regeneration system at $\mathrm{pH}$ 7.5. The final ATP concentration (supplied from the RRL) was $0.5 \mathrm{mM}$. Compounds were pre-incubated in the above mix at room temperature for $15 \mathrm{~min}$ before $25 \mathrm{ng}$ of heat denatured luciferase (Sigma, denatured at $40^{\circ} \mathrm{C}$ for $30 \mathrm{~min}$ ) was added to initiate the refolding reaction and incubated at $30^{\circ} \mathrm{C}$ for $60 \mathrm{~min}$. Luciferase activity was determined using Bright-glo reagent (Promega).

X-ray crystallography

The crystal structure of VER-155008 in complex with Hsc70/Bag-1 was determined according to the method previously described [23].

\section{Client protein degradation analysis}

Client protein degradation was determined by western blotting as previously described [26]. Her2 (ab8054, Abcam), Raf-1 (sc-133, Santa Cruz Biotechnology), and Hsp70 (SPA-810, StressGen) relative levels were determined using ECL (GE Bioscience). GAPDH (MAB374, Chemicon International) was used to show equal protein loading.

Determination of apoptosis

Activation of caspase-3/7 was measured using a homogenous caspase assay kit (G8091, Promega). Antibodies specific to the cleaved forms of either caspase-3 (Asp175, CST \#9661) or -7 (Asp198, CST \#9491) were used to determine the relative levels of caspase activation by western blotting.

Cell cycle analysis

HCT116 cells were exposed to the indicated concentrations of VER-155008 and VER-82160 for $24 \mathrm{~h}$. All cells were harvested and fixed in $70 \%$ ethanol on ice before being stained with RNaseA/propidium iodide. Data was collected on a FACSArray cytometer and analyzed with FACSDiva software (BD Bioscience).

In vivo studies

All in vivo studies were carried out according to UK Home Office guidelines and the "Guidance on the Operation of the Animals (Scientific Procedures) Act 1986". Female BALB/c mice were dosed intravenously with $25 \mathrm{mg} / \mathrm{kg}$ VER-155008 into the lateral tail vein as a solution in $10 \%$ DMSO/5\% Tween $80 / 85 \%$ saline $(v / v / v)$. Animals were sacrificed at 5, 15 and $30 \mathrm{~min}, 1,2,4$ and $6 \mathrm{~h}$ post dose.

Female BALB/c nu/nu mice were inoculated with $5 \times 10^{6}$ HCT116 cells into the right flank. Tumors were monitored for growth, and animals were dosed IV with $40 \mathrm{mg} / \mathrm{kg}$ VER-155008 on day 31 (tumor volume approximately $200-250 \mathrm{~mm}^{3}$ ). Animals were sacrificed at $15 \mathrm{~min}, 1$ and $4 \mathrm{~h}$ post dose.

Each timepoint contained three mice and blood samples were collected by cardiac puncture. Plasma was obtained by centrifugation and frozen at $-20^{\circ} \mathrm{C}$ prior to analysis. Tumors were harvested, snap frozen and stored at $-80^{\circ} \mathrm{C}$.

Bioanalysis

Tumours were homogenised with water $(3 \times$ dilution). All samples and standard lines were prepared by protein precipitation with acetonitrile containing internal standard, and centrifugation. Supernatant was evaporated to dryness and reconstituted prior to HPLC-MS/MS analysis. Samples were analyzed on a Agilent Zorbax C18 (2) column, $50 \mathrm{~mm} \times 2.1 \mathrm{~mm}, 5 \mu \mathrm{m}$ particles at $40^{\circ} \mathrm{C}$ and a flow rate of $0.3 \mathrm{~mL} / \mathrm{min}$. The mobile phase consisted of $13 \mathrm{mM}$ ammonium acetate in water containing $0.1 \%$ formic acid (A) and $13 \mathrm{mM}$ ammonium acetate in methanol containing $0.1 \%$ formic acid (B). The initial mobile phase composition was $80 \% \mathrm{~A} / 20 \% \mathrm{~B}$ over $0.3 \mathrm{~min}$, changing to $5 \% \mathrm{~A} / 95 \% \mathrm{~B}$ at $1.5 \mathrm{~min}$ (linear change), held at $5 \% \mathrm{~A} / 95 \% \mathrm{~B}$ until $2.5 \mathrm{~min}$ and returned to initial conditions at $2.6 \mathrm{~min}$ and held to $5 \mathrm{~min}$ for the column to equilibrate. The Waters Alliance HPLC was coupled to a Waters Quattro Ultima triple quadrupole mass spectrometer operating in positive 
electrospray, full MS/MS mode. Calibration lines were generated using Waters QuanLynx software and pharmacokinetic parameters were generated using WinNonLin (Pharsight Corporation).

\section{Results}

VER-155008 is a potent inhibitor of the Hsp70 family of chaperones

The structures of VER-155008 and VER-82160 are illustrated in Table 1. VER-82160 is a highly potent, orally bioavailable small molecule inhibitor of Hsp90 [22]. In a fluorescence polarization (FP) assay using $N^{6}$-(6-amino)hexyl-ATP-5-FAM as the FP probe, VER-155008 potently competed for the binding to Hsp70 with an $\mathrm{IC}_{50}$ of $0.5 \mu \mathrm{M}$ (Table 1). In addition to binding Hsp70, VER-155008 also bound, albeit at slightly reduced levels, to Hsc70 and the endoplasmic reticulum Hsp70 family member Grp78. They were, however, highly selective versus the Hsp90 chaperone exhibiting $\mathrm{IC}_{50}$ s in excess of $200 \mu \mathrm{M}$ against Hsp90 $\beta$. Due to the Hsp70 protein concentration required to generate a large enough assay window, the FP assay is not sufficiently sensitive to discriminate compounds with sub $500 \mathrm{nM} \mathrm{IC} \mathrm{IC}_{50}$ s. To evaluate the true affinity of the adenosine inhibitors for Hsp70, we developed a surface plasmon resonance (SPR) direct binding assay. Double His-tagged Hsp70 was immobilised on a Biacore sensor chip and the $K_{\mathrm{D}}$ of VER-155008 determined. This was found to be
$0.3 \mu \mathrm{M}$. The ability of VER-155008 to inhibit the steady state activity of purified full-length Hsp70 in the absence of any co-chaperones was evaluated. VER-155008 inhibited the ATP turnover of Hsp70 by $24.5 \%$ at $30 \mu \mathrm{M}$ and $48.7 \%$ at $100 \mu \mathrm{M}$ (Fig. 1a). This correlated closely with inhibition of refolding of heat denatured luciferase by rabbit reticulocyte lysate. At 50 and $100 \mu \mathrm{M}$, VER-155008 inhibited luciferase refolding 37.8 and $47.5 \%$, respectively (Fig. 1b). VER-155008 did not inhibit luciferase or the coupled ADP detection step in ADP Hunter Plus assay at any of the concentrations tested (data not shown). Against a small panel of protein kinases, VER-155008 exhibited an $\mathrm{IC}_{50}>10 \mu \mathrm{M}$ versus Aurora $\mathrm{A},>50 \mu \mathrm{M}$ versus $\mathrm{CDK} 2$ and $>200 \mu \mathrm{M}$ versus CHK1, PDPK1 and GSK3 $\beta$.

VER-155008 binds to the ATPase site of Hsc70/Bag-1

The X-ray crystal structure of VER-155008 solved to $2.2 \AA$ resolution overlaid with the crystal structure of ATP bound to Hsc70/Bag-1 is shown in Fig. 1c. The crystal form of Hsp70 obtained gave low resolution structures therefore Hsc70/Bag-1 was selected for crystallography as Hsc70 shows high sequence homology in the ATPase domain to Hsp70 and ATP adopts the same conformation and binding mode, with highly similar adenosine nucleotide-protein interactions. VER-155008 binds in the ATPase site of Hsc70/Bag-1 and the adenosine portion of VER-155008 adopts corresponding protein interactions as the adenosine portion of ATP. The additional potency of VER-155008 is likely through the displacement of a water group and the

Table 1 Structure and in vitro activity of VER-155008 and VER-82160

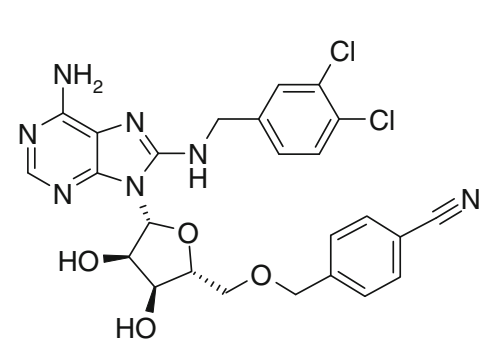

VER-155008<smiles>CCNC(=O)c1cc2c(-c3cc(OCCN(CC)CC)c(Cl)cc3Cl)nc(N)nc2s1</smiles>

VER-82160<smiles>C=CCNC1=C(C[C@@H](C)C[C@H](OC)[C@@H](O)[C@H](C)/C=C(\C)C(OC)C(C)OC)C(=O)C(NC(=O)/C(C)=C/C=C\C(C)OC)=CC1=O</smiles>

17-AAG

\begin{tabular}{|c|c|c|c|c|c|}
\hline Cmpd & Hsp70 FP IC $\mathrm{I}_{50}(\mu \mathrm{M})$ & Hsc70 FP IC I0 $_{50}(\mu \mathrm{M})$ & Grp78 FP IC I0 $_{50}(\mu \mathrm{M})$ & Hsp70 $K_{D}(\mu M)$ & Hsp90 FP IC ${ }_{50}(\mu \mathrm{M})$ \\
\hline VER-155008 & $0.5 \pm 0.15$ & 2.6 & $2.6 \pm 0.39$ & 0.3 & $>200$ \\
\hline \multirow[t]{2}{*}{ VER-82160 } & ND & ND & $\mathrm{ND}$ & ND & $0.056 \pm 0.012$ \\
\hline & BT474 $\mathrm{GI}_{50}(\mu \mathrm{M})$ & MB-468 $\mathrm{GI}_{50}$ & HCT116 & ${ }_{50}(\mu \mathrm{M})$ & HT29 $\mathrm{GI}_{50}(\mu \mathrm{M})$ \\
\hline VER-155008 & $10.4 \pm 1.9$ & $14.4 \pm 1.9$ & $5.3 \pm 2$. & & 12.8 \\
\hline VER-82160 & $0.073 \pm 0.025$ & $0.123 \pm 0.041$ & $0.154 \pm$ & & $0.073 \pm 0.014$ \\
\hline
\end{tabular}

Values are the average of at least two independent determinations $\pm \mathrm{SD}$ 
Fig. 1 VER-155008 inhibits the intrinsic ATPase activity of Hsp70 and binds in the ATPase pocket. a Inhibition of fulllength Hsp70 ATPase activity by VER-155008. b VER155008 inhibited the refolding of heat denatured luciferase by rabbit reticulocyte lysate.

Values are the mean of at least three determinations \pm SD.

c X-ray crystal structure of VER-155008 (cyan) overlaid with ATP (yellow) bound to Hsc70:Bag-1. Hsc70 is shown in grey and Bag-1 in blue. For atomic coordinates and structure factors, see PDB codes 3FZL and $3 \mathrm{FZF}$, respectively (color figure online)
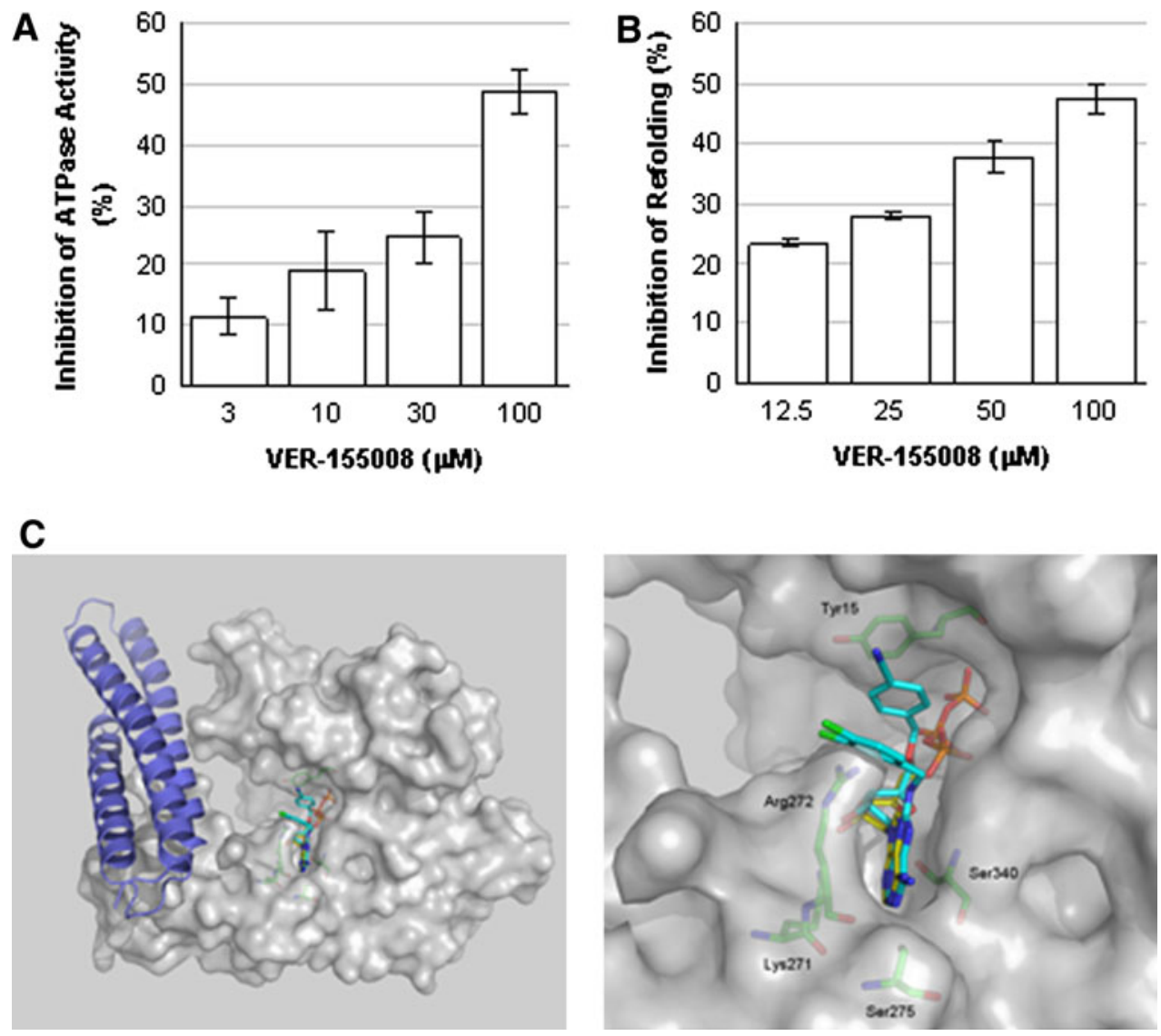

stabilization of the complex of inter- and intramolecular $\pi$-stacking between the 8-aminobenzyl and 5-benzyl substituents. In addition, an intramolecular $\mathrm{H}$-bond between the $8-\mathrm{NH}$ and $5^{\prime}-\mathrm{CH}_{2} \mathrm{O}$ is also likely to stabilize the bound ligand.

VER-155008 inhibits cell proliferation of multiple human tumor cell lines in vitro and induces the degradation of Hsp90 client proteins in HCT116 and BT474 cells

VER-155008 inhibited the proliferation of a variety of human colon and breast tumor cell lines with moderate activity (Table 1). HCT116 cells were particularly sensitive to Hsc70/Hsp70 inhibition by VER-155008 with a $\mathrm{GI}_{50}$ of $5.3 \mu \mathrm{M}$.

Small molecule inhibitors of Hsp90 have a molecular signature that comprises the depletion (through proteasomic degradation) of client proteins and the induction of Hsp70. Dual targeting of Hsc70 and Hsp70 by siRNA induces Hsp90 client protein degradation in HCT116 cells. The Hsp90 inhibitor 17-AAG induced a clear degradation of Her2 and Raf-1, and upregulation of Hsp70 in both BT474 and HCT116 cell lines (Fig. 2). Exposure of BT474 or HCT116 cells to VER-155008 induced the degradation of Her2 and Raf-1 in both cell lines at a concentration of $40 \mu \mathrm{M}$
(Fig. 2) thereby mimicking the cellular response observed with the dual targeting of Hsc70 and Hsp70 by siRNA. In contrast to 17-AAG, VER-155008 did not induce Hsp70; a clear differential between Hsp70 and Hsp90 inhibitors.

VER-155008 induces apoptosis in BT474 human breast tumor cell line

We have previously shown that following Hsp90 inhibition with NVP-AUY922 or 17-AAG, deferential caspase dependent apoptotic responses are observed [26, 27]. For example, the Her2 positive breast carcinoma BT474 undergoes massive caspase dependent apoptosis while the colon carcinoma cell line HCT116 does not. In fact, NVPAUY922 is predominantly cytostatic in this cell line. Of the four cell lines tested, only BT474 cells underwent any caspase-3/7 dependent apoptosis following treatment for $24 \mathrm{~h}$ with $0.5 \mu \mathrm{M}$ VER-82160. In this cell line, VER82160 increased caspase-3/7 activity by 10.6 -fold. In the other three cell lines, the increase in caspase-3/7 activity was 1.0-2.2-fold (Fig. 3a). We therefore sought to evaluate the potential of VER-155008 to induce apoptosis in various carcinoma cell lines. The apoptotic potential of VER155008 was again cell line dependent. BT474 was the most sensitive cell line to apoptosis induction by VER-155008; 
Fig. 2 VER-155008 induces client protein degradation in HCT116 and BT474 carcinoma cells. Western blot analysis of Her2, Raf-1, Hsp70 and GAPDH levels in BT474 (left) or HCT116 (right) cells following $24 \mathrm{~h}$ exposure to 17-AAG $(0.25 \mu \mathrm{M}$ BT474 or $0.5 \mu \mathrm{M}$ HCT116) or VER-155008

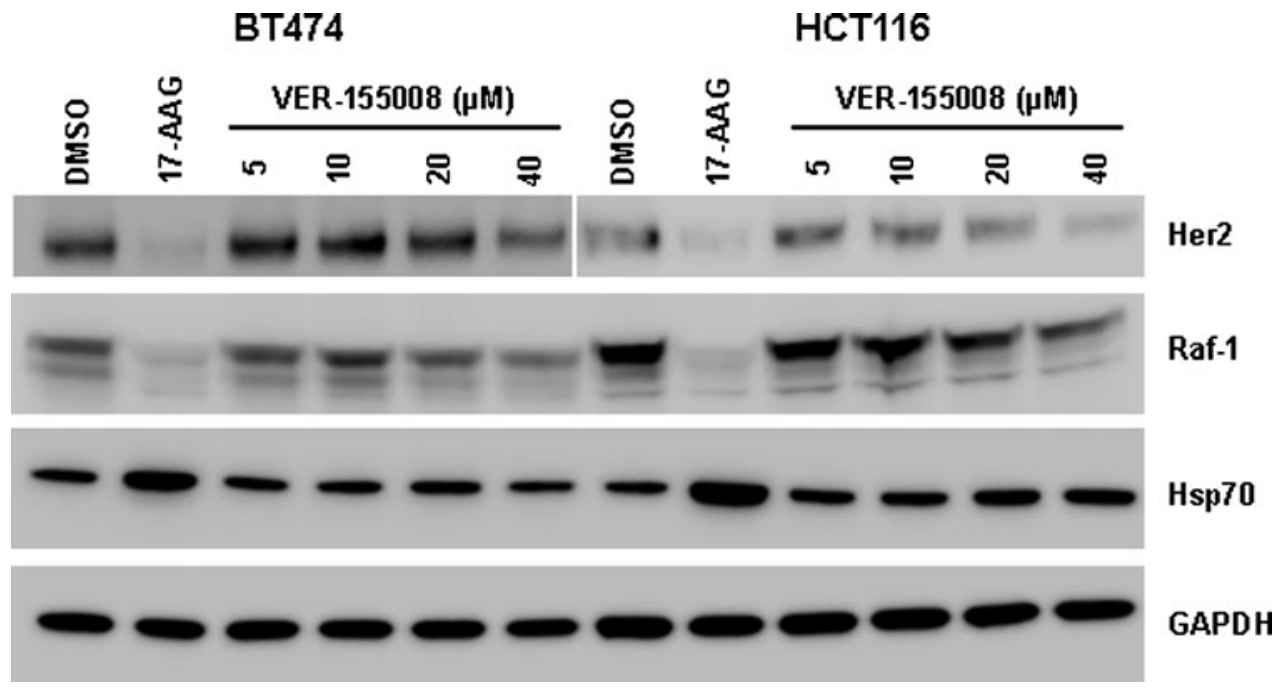

A

Fig. 3 VER-155008 induces apoptosis in human tumor cell lines. a BT474, MDA-MB-468, HCT116 or HT29 cells were exposed to $0.5 \mu \mathrm{M}$ VER- 82160 for $24 \mathrm{~h}$. b BT474, MDA-MB468 , HCT116 or HT29 were exposed to $20 \mu \mathrm{M}$ (white) or $40 \mu \mathrm{M}$ (grey) VER-155008 for $24 \mathrm{~h}$. The amount of active caspase-3/7 was determined using a homogenous caspase assay. Values are the average of at least three determinations \pm SD. c VER-155008 reduced the colony forming ability of HCT116 or HT29 cells following a $48 \mathrm{~h}$ exposure to VER-155008. Cells were allowed to grow out for a further 7-10 days before being stained with formaldehyde/crystal violet

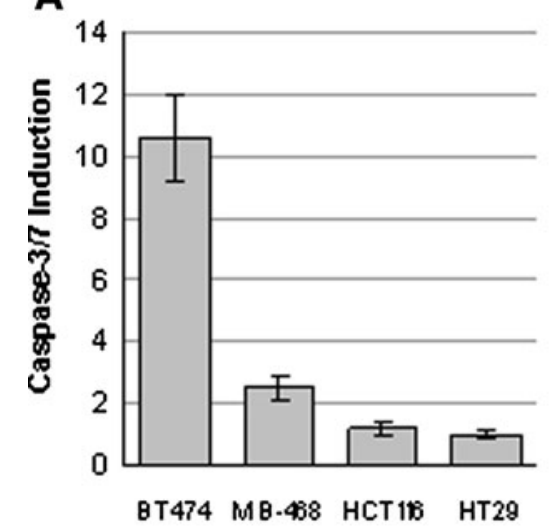

B
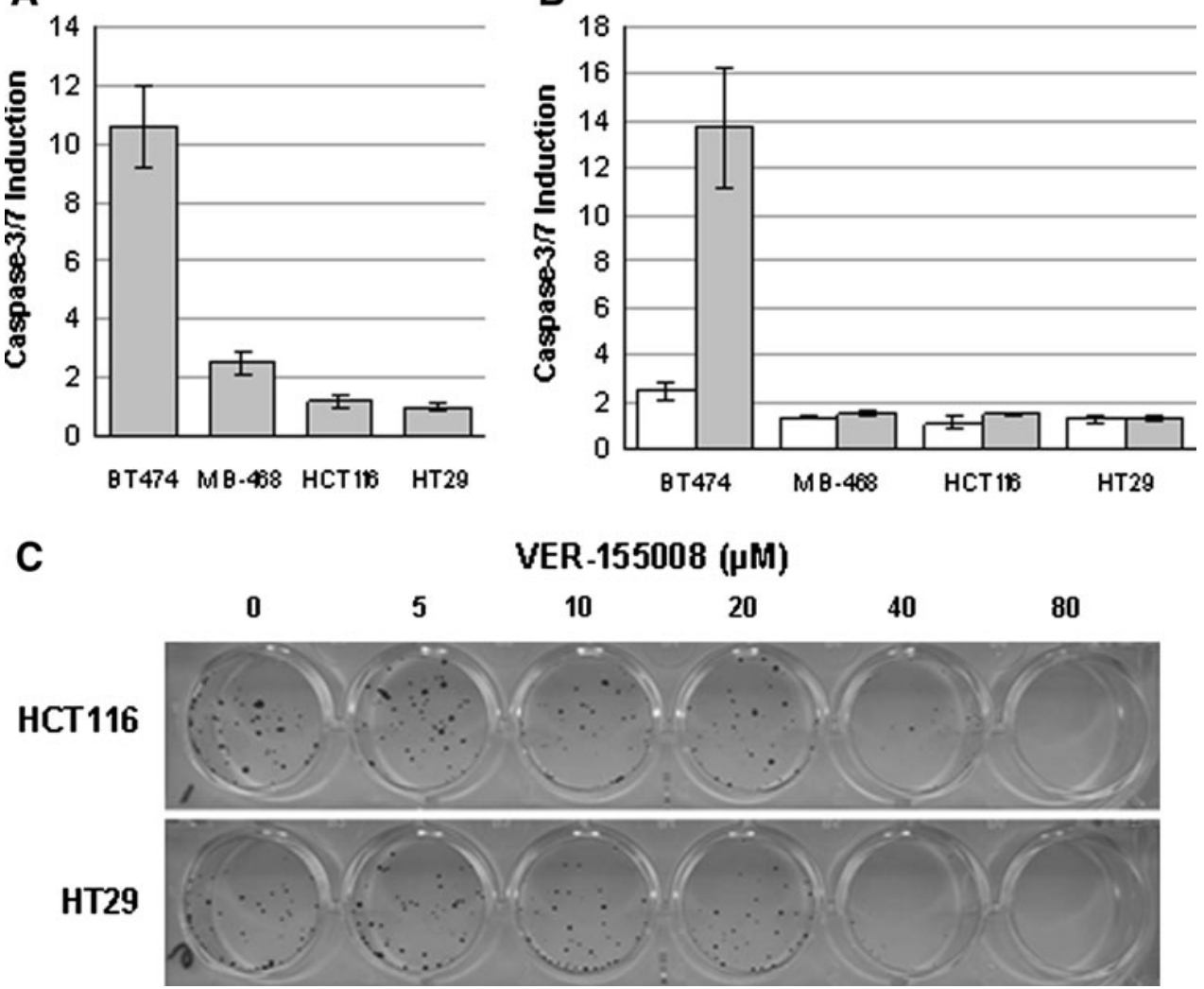

VER-155008 ( $\mu \mathrm{M})$ 
3/7 activation whilst VER-155008 as a single agent did not induce any caspase activation at concentrations up to $40 \mu \mathrm{M}$. In stark contrast, the combination of VER-82160 or 17-AAG with VER-155008 resulted in activation of caspase-3/7 dependent apoptosis (Fig. 4a). Caspase-3/7 levels were increased 2.9, 4.0 and 4.3-fold, respectively following the treatment of HCT116 cells with $0.5 \mu \mathrm{M}$ VER-82160 and 10,20 and $40 \mu \mathrm{M}$ VER-155008 for $24 \mathrm{~h}$. Under identical conditions, $0.5 \mu \mathrm{M} 17-\mathrm{AAG}$ in combination with 10,20 or $40 \mu \mathrm{M}$ VER-155008 induced caspase-3/7 levels 3.2, 4.8 and 5.5-fold, respectively. Neither VER-82160 nor 17-AAG had any effect on caspase-3/7 activation when administered alone inducing caspase-3/7 levels 1.2 and 1.5fold at $0.5 \mu \mathrm{M}$. The levels of caspase induction were also dependent on the concentration of VER-82160 or 17-AAG present. Maximal induction of caspase activity was observed at concentrations of VER- 82160 between 0.5 and $1 \mu \mathrm{M}$ (data not shown). Of the other three cell lines tested, the combination of VER-82160 and VER-155008 had no effect on caspase-3/7 activation in MDA-MB-468 or HT29 cells increasing caspase-3/7 levels 1.5 and 1.6-fold, respectively. In BT474, the combination of VER-82160 and VER-155008 appeared to activate caspase-3/7 levels above that expected for the two agents to be working additively (Fig. 4b). However, the increased level of caspase activation by the combination was only small. These results were confirmed by western blotting. Treatment of HCT116 cells for $24 \mathrm{~h}$ with either 10 or $20 \mu \mathrm{M}$ VER155008 in the presence of $0.5 \mu \mathrm{M}$ VER-82160 led to an increase in cleaved caspase- 3 and -7 levels as judged by western blotting (Fig. 4c). In the absence of VER-82160, no cleaved caspase- 3 or -7 could be detected. Twenty-four hour exposure to the combination of $10 \mu \mathrm{M}$ VER-155008 and $0.5 \mu \mathrm{M}$ VER-82160 was necessary to see activation of caspase-3 and -7; no caspase cleavage was observed after only $6 \mathrm{~h}$.

We subsequently determined the viability of HCT116 cells following $48 \mathrm{~h}$ co-treatment of VER-155008 with VER-82160 or 17-AAG. VER-155008 had no effect on survival when administered as a single agent resulting in a 4 and $8 \%$ reduction in survival following treatment with 10 and $20 \mu \mathrm{M}$ VER-155008, respectively (Fig. 4d). Likewise, $0.5 \mu \mathrm{M}$ VER-82160 or 17-AAG reduced survival by 21 and $15 \%$, respectively. The combination of VER-82160 with VER-155008 or 17-AAG with VER-155008 dramatically reduced survival compared to any of the three agents alone. Exposure of HCT116 cells to $0.5 \mu \mathrm{M}$ VER-82160 in combination with 10 or $20 \mu \mathrm{M}$ VER-155008 resulted in a 55 and $80 \%$ reduction in survival while $0.5 \mu \mathrm{M} 17-\mathrm{AAG}$ in combination with the same concentrations of VER-155008 reduced survival even further by 70 and $91.5 \%$.

The cell cycle response of HCT116 cells to VER-82160 and VER-155008 either administered singularly or in combination was evaluated. Treatment of HCT116 cells with $0.5 \mu \mathrm{M}$ VER-82160 for $24 \mathrm{~h}$ resulted in predominantly G1 arrest (from $47.5 \%$ in untreated cells to $70.6 \%$ ) with very little apoptosis as judged by the sub-G1 DNA content (5.0\% of cells; Fig. 4e). In comparison, exposure of HCT116 cells to VER-155008 resulted in G1 arrest at lower doses $(20 \mu \mathrm{M}, 61.1 \%)$ converting to $\mathrm{G} 2 / \mathrm{M}$ arrest at higher concentrations $(17.8 \% \mathrm{G} 2 / \mathrm{M}$ at $20 \mu \mathrm{M}$ increasing to $28.8 \%$ at $40 \mu \mathrm{M})$. This increase in $\mathrm{G} 2 / \mathrm{M}$ arrest also correlated with an increase in the fraction of cells with a subG1 DNA content $(5.3 \%$ at $20 \mu \mathrm{M}$ rising to $15.6 \%$ by $40 \mu \mathrm{M})$. The combination treatment of $0.5 \mu \mathrm{M}$ VER-82160 with either 20 or $40 \mu \mathrm{M}$ VER-155008 resulted in increased apoptosis (21.3 and $20.6 \%$ sub-G1, respectively). No major cell cycle phase arrest was apparent in the combination treated cells.

\section{In vivo pharmacokinetics of VER-155008}

The in vivo pharmacokinetics of VER-155008 was investigated in tumor and non-tumor bearing mice. VER-155008 has limited oral absorption and was therefore administered via the IV route. Following a single $25 \mathrm{mg} / \mathrm{kg}$ IV dose to naïve female BALB/c mice, VER-155008 displayed a moderate plasma clearance of $49 \mathrm{~mL} / \mathrm{min} / \mathrm{kg}$ which was reflected in a short half-life of $0.6 \mathrm{~h}$ (Fig. 5a). VER-155008 was subsequently dosed at $40 \mathrm{mg} / \mathrm{kg}$ IV to HCT116 tumor bearing nude BALB/c mice and compound was shown to distribute to the tumor tissue, with a longer tumor half-life than the plasma (1.5 vs. 0.5 h, Fig. $5 b$ ). In summary, VER155008 exhibited rapid clearance and measured tumor levels were below the predicted pharmacologically active dose.

\section{Discussion}

In recent years, targeting $\mathrm{Hsp} 90$ has emerged as an exciting therapeutic intervention for a wide variety of human cancers. This is reflected in the large number of small molecules with distinct chemotypes targeting the ATP binding pocket in pre-clinical and clinical development [28]. Through its ability to control the activity and stability of many client proteins involved in the oncogenic process, targeting Hsp90 has the potential to affect all the hallmarks of cancer. It is well documented that the Hsp70 family of chaperones have an anti-apoptotic function and targeting the induction of Hsp70 following Hsp90 inhibition sensitized tumor cells to Hsp90 inhibition [29-31].

The effect of targeting Hsp70 with RNAi or anti-sense has had conflicting results on cancer cell proliferation and survival. Several reports suggest that down regulating 
A

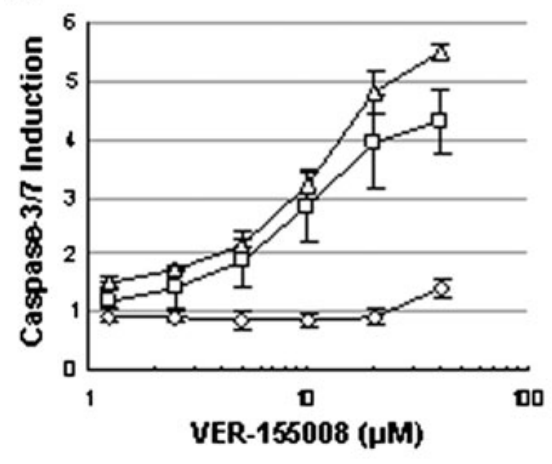

C

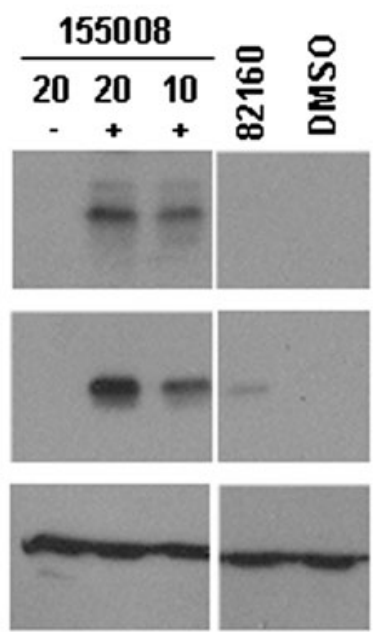

B

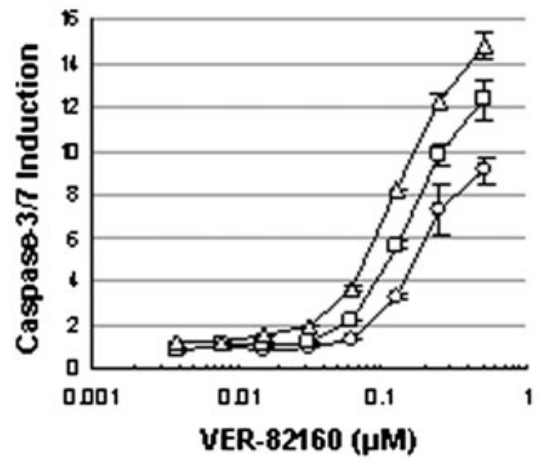

D
E

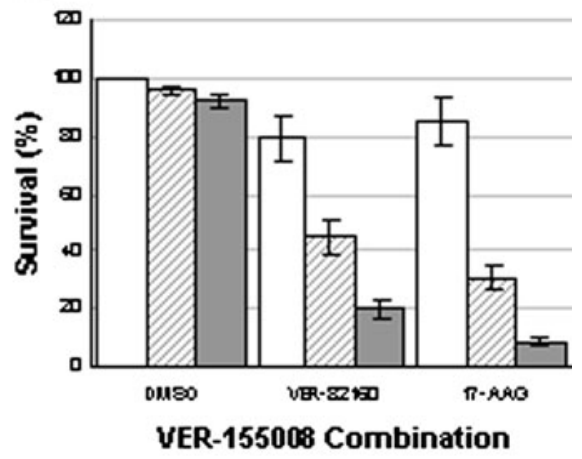

Caspase-3

Caspase-7

GAPDH 
Fig. 5 In vivo pharmacokinetic properties of VER-155008 in normal and HCT116 tumor bearing animals. a Single dose pharmacokinetics of VER155008 following $25 \mathrm{mg} / \mathrm{kg}$ IV dose to female BALB/c mice. b Plasma (circle) and tumor (triangle) concentrations following $40 \mathrm{mg} / \mathrm{kg}$ IV dose of VER-155008 to HCT116 tumor bearing mice
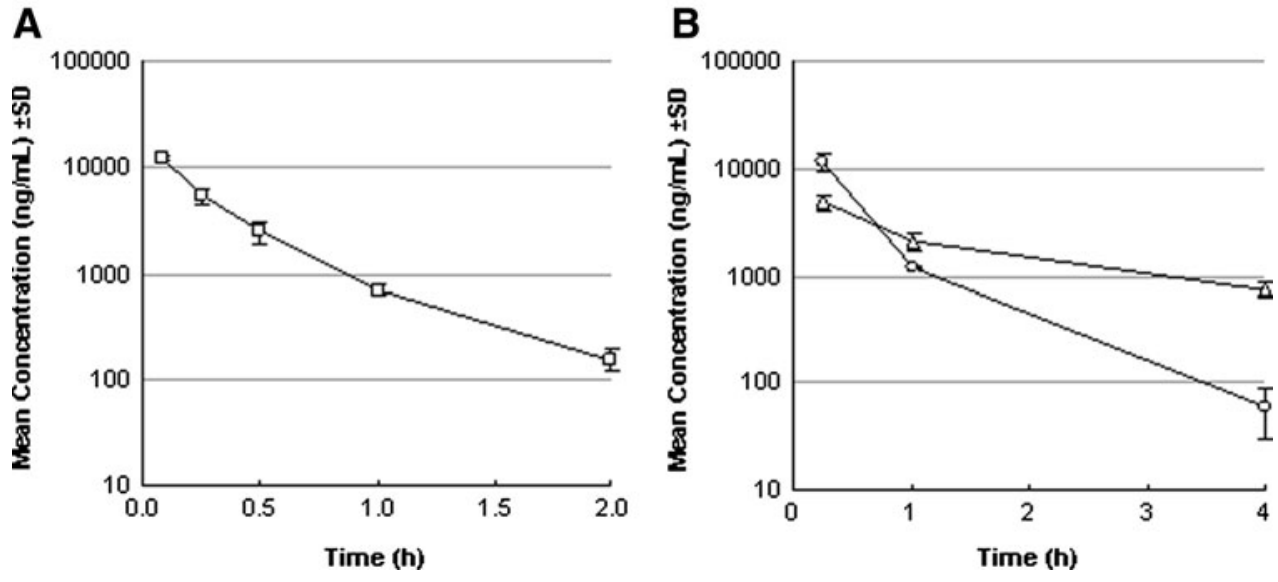

Hsp70 was sufficient to induce tumor specific death [12, $15,16]$ while others suggest that either Hsc70 or Hsp70 is dispensable for tumor cell viability [21, 30]. Our own data, in which either Hsc70 or Hsp70 was depleted in a panel of ten solid cancer cell lines support the later observation (data not shown). Recent work by Powers and colleagues demonstrates that the dual targeting of Hsc70 and Hsp70 is necessary and sufficient to induce tumor-specific apoptosis in the cell models they tested. Silencing of Hsc70 and Hsp70 with siRNA induced proteasome-dependent degradation of Hsp90 client proteins, G1 cell cycle arrest and extensive tumor specific apoptosis as well as increased tumor cell apoptosis in response to Hsp90 inhibition by 17 AAG [21].

Dual inhibition of Hsc70/Hsp70 with the small molecule inhibitor VER-155008 mimics the cellular phenotype observed when Hsc70/Hsp70 were dually silenced with siRNA. Targeting Hsc70/Hsp70 with VER-155008 resulted in depletion of the Hsp90 client proteins Her2 and Raf-1 in both BT474 and HCT116 carcinoma cell lines. This client protein degradation correlated closely with the ability of VER-155008 to inhibit the ATPase activity of Hsp70 and the refolding of heat denatured luciferase, both of which were around 100-fold higher than the affinity of VER155008 measured by a simple binding assay. VER-155008 induced cell death that was both caspase-3/7 dependent and independent when administered as a single agent and the cell death response was cell line specific. As a single agent, VER-155008 induced caspase-3/7 dependent apoptosis in BT474 cells but not HCT116, MDA-MB-468 or HT29 cells. Identical cellular responses were observed with the Hsp90 inhibitors 17-AAG and VER-82160. The combination of an Hsp90 inhibitor (VER-82160 or 17-AAG) and our small molecule Hsc70/Hsp70 inhibitor (VER-155008) resulted in increased caspase-3/7 dependent apoptosis in HCT116 colon carcinoma cells but not HT29 or MDAMB-468 when administered in combination compared to when administered as single agents. The concentration of
VER-155008 require to induce cell death closely correlated with that required to induce client protein degradation suggesting that this is occurring via an Hsp70-dependent mechanism. Further work is required to define the cell death pathways utilized in response to Hsc70/Hsp70 inhibition both alone and in combination with an Hsp90 inhibitor, and the factors that determine how individual cells respond. This information could be useful in guiding clinical development and allow the stratification of patients based on their predicted response rather than the client proteins expressed.

Developing small molecule inhibitors of Hsp90 has proved relatively straight forward (as exemplified by the diverse nature of inhibitors in pre-clinical and clinical development). While many have suggested Hsp70 as an excellent target for therapeutic intervention in the treatment of cancer, no drug-like inhibitors have yet emerged [32]. Previously described inhibitors have centred on 15deoxyspergulin [33, 34], dihydropyrimidines [35, 36] and 3 '-sulfogalactolipids [37, 38]. While these compounds have demonstrated effects on Hsc70/Hsp70 chaperone activity in vitro and possess modest anti-tumor cellular activity $\left(\mathrm{GI}_{50}\right.$ of 2.4-50 $\mu \mathrm{M}$ ), no evidence exists for their cellular activity being via Hsc70/Hsp70 inhibition. In addition, these molecules are of high molecular weight and possess functionalities that break Lipinski's rules of 'drug-like' [39].

Why has targeting Hsp90 proved so fruitful and Hsc70/ Hsp70 so difficult? We suggest the very nature of the ATP binding pocket is the reason why targeting this functionality of Hsc70/Hsp70 has proved particularly challenging so far. Hsc70/Hsp70 are members of the actin-like family of ATPases while Hsp90 belongs to the GHKL family [40]. This results in binding sites that are structurally very different. In Hsc70/Hsp70, the $\beta$ and $\gamma$ phosphates of ATP (which correspond to a large fraction of the ATP binding affinity) are stabilized in a buried binding mode by more polar interactions with the protein, several of which are water mediated. This creates two difficulties for drug 
discovery: gaining potency via these polar interactions and retaining good cell penetrative properties. Gaining potency via polar interactions is difficult in general because these interactions are already formed with water in the unbound state. Therefore, it is frequently argued that little is gained per interaction in the bound state. Generating 'good' multiple polar interactions (via hydrogen-bonds) is equally difficult as they need to be directional and precise [41, 42]. Binding to Hsc70/Hsp70 via such interactions, whilst still trying to meet Lipinski [39] and Veber's [43] criteria of 'orally bioavailable drug-likeness', is extremely challenging. For example, in the case of VER-155008, trying to mimic these interactions has resulted in a compound with a high polar surface area (PSA, 164.4), the number of $\mathrm{O}+\mathrm{N}$ atoms $>10$ (11) and a high molecular weight (555). In contrast to Hsc70/Hsp70, the ATP binding pocket of Hsp90 has a well balanced hydrophilic/hydrophobic character with ATP bound with the adenine portion buried towards the bottom of the pocket and the $\alpha, \beta, \gamma$-phosphates pointing out into solvent. This has allowed the discovery and development of much more drug-like molecules (e.g. VER-82160; $\mathrm{PSA}=93.4, \mathrm{O}+\mathrm{N}=7$ and $\mathrm{MW}=482$ ). Finally, the affinity of Hsc70/Hsp70 for ATP may be an additional hurdle regarding its druggability. The affinity of Hsc70/Hsp70 for ATP is reported to be around $1 \mu \mathrm{M}$ (though this varies according to the method used) while for Hsp90 the value is much higher at $200-400 \mu \mathrm{M}$. Achieving cell activity of under $100 \mathrm{nM}$, and therefore the possibility of in vivo activity, will require inhibitors with $K_{\mathrm{D}} \mathrm{s}$ of $<1 \mathrm{nM}$ and slow, tight binding kinetics. We suggest that, given the highly polar nature of the Hsc70/Hsp70 ATP binding site, this will prove extremely challenging, if not impossible.

Our data and that of Powers et al. suggests that inhibiting Hsc70/Hsp70 as a single agent is likely to recapitulate the phenotype, specificity and activity of a Hsp90 inhibitor of which there are many in the clinic. However, the exciting and potentially useful clinical utility for Hsc70/ Hsp70 inhibitors could be in the ability to convert cytostatic responses to Hsp90 inhibitors into tumor cell death. Identifying the factors that predict whether the tumor response is likely to be cytotoxic or cytostatic is therefore of critical importance. Inhibiting the Hsc70/Hsp70 family of molecular chaperones still offers an exciting anti-cancer therapeutic strategy; however, alternative ways of disrupting the chaperone activity are needed. Specifically disrupting the protein:protein interactions between Hsc70/ Hsp70 and one of its co-chaperones with a designed small molecule may prove a more amenable area of cancer drug discovery.

Acknowledgments We thank Jonathan Moore and Nicolas Foloppe for critically reading the manuscript.

\section{References}

1. Mayer MP, Bukau B (2005) Hsp70 chaperones: cellular functions and molecular mechanism. Cell Mol Life Sci 62(6):670-684

2. Nollen EA, Morimoto RI (2002) Chaperoning signaling pathways: molecular chaperones as stress-sensing 'heat shock' proteins. J Cell Sci 115(Pt 14):2809-2816

3. Young JC, Agashe VR, Siegers K, Hartl FU (2004) Pathways of chaperone-mediated protein folding in the cytosol. Nat Rev Mol Cell Biol 5(10):781-791

4. Daugaard M, Rohde M, Jaattela M (2007) The heat shock protein 70 family: highly homologous proteins with overlapping and distinct functions. FEBS Lett 581(19):3702-3710

5. Young JC, Barral JM, Ulrich HF (2003) More than folding: localized functions of cytosolic chaperones. Trends Biochem Sci 28(10):541-547

6. Garrido C, Brunet M, Didelot C, Zermati Y, Schmitt E, Kroemer G (2006) Heat shock proteins 27 and 70: anti-apoptotic proteins with tumorigenic properties. Cell Cycle 5(22):2592-2601

7. Sriram M, Osipiuk J, Freeman B, Morimoto R, Joachimiak A (1997) Human Hsp70 molecular chaperone binds two calcium ions within the ATPase domain. Structure 5(3):403-414

8. Sondermann H, Scheufler C, Schneider C, Hohfeld J, Hartl FU, Moarefi I (2001) Structure of a Bag/Hsc70 complex: convergent functional evolution of $\mathrm{Hsp} 70$ nucleotide exchange factors. Science 291(5508):1553-1557

9. Mosser DD, Morimoto RI (2004) Molecular chaperones and the stress of oncogenesis. Oncogene 23(16):2907-2918

10. Sliutz G, Karlseder J, Tempfer C, Orel L, Holzer G, Simon MM (1996) Drug resistance against gemcitabine and topotecan mediated by constitutive Hsp70 overexpression in vitro: implication of quercetin as sensitiser in chemotherapy. Br J Cancer 74(2): 172-177

11. Pocaly M, Lagarde V, Etienne G, Ribeil JA, Claverol S, Bonneu M, Moreau-Gaudry F, Guyonnet-Duperat V, Hermine O, Melo JV, Dupouy M, Turcq B, Mahon FX, Pasquet JM (2007) Overexpression of the heat-shock protein 70 is associated to imatinib resistance in chronic myeloid leukemia. Leukemia 21(1):93-101

12. Nylandsted J, Brand K, Jaattela M (2000) Heat shock protein 70 is required for the survival of cancer cells. Ann NY Acad Sci 926:122-125

13. Nylandsted J, Rohde M, Brand K, Bastholm L, Elling F, Jaattela M (2000) Selective depletion of heat shock protein 70 (Hsp70) activates a tumor-specific death program that is independent of caspases and bypasses Bcl-2. Proc Natl Acad Sci USA 97(14):7871-7876

14. Rohde M, Daugaard M, Jensen MH, Helin K, Nylandsted J, Jaattela M (2005) Members of the heat-shock protein 70 family promote cancer cell growth by distinct mechanisms. Genes Dev 19(5):570-582

15. Schmitt E, Maingret L, Puig PE, Rerole AL, Ghiringhelli F, Hammann A, Solary E, Kroemer G, Garrido C (2006) Heat shock protein 70 neutralization exerts potent antitumor effects in animal models of colon cancer and melanoma. Cancer Res 66(8): 4191-4197

16. Nylandsted J, Wick W, Hirt UA, Brand K, Rohde M, Leist M, Weller M, Jaattela M (2002) Eradication of glioblastoma, and breast and colon carcinoma xenografts by Hsp70 depletion. Cancer Res 62(24):7139-7142

17. Whitesell L, Lindquist SL (2005) HSP90 and the chaperoning of cancer. Nat Rev Cancer 5(10):761-772

18. Mimnaugh EG, Xu W, Vos M, Yuan X, Isaacs JS, Bisht KS, Gius D, Neckers L (2004) Simultaneous inhibition of hsp 90 and the proteasome promotes protein ubiquitination, causes endoplasmic reticulum-derived cytosolic vacuolization, and enhances antitumor activity. Mol Cancer Ther 3(5):551-566 
19. Workman P (2004) Combinatorial attack on multistep oncogenesis by inhibiting the Hsp90 molecular chaperone. Cancer Lett 206(2):149-157

20. Banerji U, O’Donnell A, Scurr M, Pacey S, Stapleton S, Asad Y, Simmons L, Maloney A, Raynaud F, Campbell M, Walton M, Lakhani S, Kaye S, Workman P, Judson I (2005) Phase I pharmacokinetic and pharmacodynamic study of 17-allylamino, 17-demethoxygeldanamycin in patients with advanced malignancies. J Clin Oncol 23(18):4152-4161

21. Powers MV, Clarke PA, Workman P (2008) Dual targeting of HSC70 and HSP72 inhibits HSP90 function and induces tumorspecific apoptosis. Cancer Cell 14(3):250-262

22. Brough PA, Barril X, Borgognoni J, Chene P, Davies NG, Davis B, Drysdale MJ, Dymock B, Eccles SA, Garcia-Echeverria C, Fromont C, Hayes A, Hubbard RE, Jordan AM, Jensen MR, Massey A, Merrett A, Padfield A, Parsons R, Radimerski T, Raynaud FI, Robertson A, Roughley SD, Schoepfer J, Simmonite H, Sharp SY, Surgenor A, Valenti M, Walls S, Webb P, Wood M, Workman P, Wright L (2009) Combining hit identification strategies: fragment-based and in silico approaches to orally active 2-aminothieno[2, 3-d]pyrimidine inhibitors of the Hsp90 molecular chaperone. J Med Chem 52(15):4794-4809

23. Williamson DS, Borgognoni J, Clay A, Daniels Z, Dokurno P, Drysdale MJ, Foloppe N, Francis GL, Graham CJ, Howes R, Macias AT, Murray JB, Parsons R, Shaw T, Surgenor AE, Terry L, Wang Y, Wood M, Massey AJ (2009) Novel adenosinederived inhibitors of $70 \mathrm{kDa}$ heat shock protein, discovered through structure-based design. J Med Chem 52(6):1510-1513

24. Schumacher RJ, Hurst R, Sullivan WP, McMahon NJ, Toft DO, Matts RL (1994) ATP-dependent chaperoning activity of reticulocyte lysate. J Biol Chem 269(13):9493-9499

25. Gross M, Hessefort S (1996) Purification and characterization of a 66-kDa protein from rabbit reticulocyte lysate which promotes the recycling of hsp 70. J Biol Chem 271(28):16833-16841

26. Eccles SA, Massey A, Raynaud FI, Sharp SY, Box G, Valenti M, Patterson L, de Haven BA, Gowan S, Boxall F, Aherne W, Rowlands M, Hayes A, Martins V, Urban F, Boxall K, Prodromou C, Pearl L, James K, Matthews TP, Cheung KM, Kalusa A, Jones K, McDonald E, Barril X, Brough PA, Cansfield JE, Dymock B, Drysdale MJ, Finch H, Howes R, Hubbard RE, Surgenor A, Webb P, Wood M, Wright L, Workman P (2008) NVP-AUY922: a novel heat shock protein 90 inhibitor active against xenograft tumor growth, angiogenesis, and metastasis. Cancer Res 68(8):2850-2860

27. Jensen MR, Schoepfer J, Radimerski T, Massey A, Guy CT, Brueggen J, Quadt C, Buckler A, Cozens R, Drysdale MJ, GarciaEcheverria C, Chene P (2008) NVP-AUY922: a small molecule HSP90 inhibitor with potent antitumor activity in preclinical breast cancer models. Breast Cancer Res 10(2):R33

28. Taldone T, Gozman A, Maharaj R, Chiosis G (2008) Targeting Hsp90: small-molecule inhibitors and their clinical development. Curr Opin Pharmacol 8(4):370-374
29. Guo F, Rocha K, Bali P, Pranpat M, Fiskus W, Boyapalle S, Kumaraswamy S, Balasis M, Greedy B, Armitage ES, Lawrence N, Bhalla K (2005) Abrogation of heat shock protein 70 induction as a strategy to increase antileukemia activity of heat shock protein 90 inhibitor 17-allylamino-demethoxy geldanamycin. Cancer Res 65(22):10536-10544

30. Gabai VL, Budagova KR, Sherman MY (2005) Increased expression of the major heat shock protein Hsp72 in human prostate carcinoma cells is dispensable for their viability but confers resistance to a variety of anticancer agents. Oncogene 24(20):3328-3338

31. Zaarur N, Gabai VL, Porco JA Jr, Calderwood S, Sherman MY (2006) Targeting heat shock response to sensitize cancer cells to proteasome and Hsp90 inhibitors. Cancer Res 66(3):1783-1791

32. Powers MV, Clarke PA, Workman P (2009) Death by chaperone: HSP90, HSP70 or both? Cell Cycle 8(4):518-526

33. Nadler SG, Dischino DD, Malacko AR, Cleaveland JS, Fujihara SM, Marquardt H (1998) Identification of a binding site on Hsc70 for the immunosuppressant 15-deoxyspergualin. Biochem Biophys Res Commun 253(1):176-180

34. Fewell SW, Day BW, Brodsky JL (2001) Identification of an inhibitor of hsc70-mediated protein translocation and ATP hydrolysis. J Biol Chem 276(2):910-914

35. Fewell SW, Smith CM, Lyon MA, Dumitrescu TP, Wipf P, Day BW, Brodsky JL (2004) Small molecule modulators of endogenous and co-chaperone-stimulated Hsp70 ATPase activity. J Biol Chem 279(49):51131-51140

36. Wisen S, Gestwicki JE (2008) Identification of small molecules that modify the protein folding activity of heat shock protein 70 . Anal Biochem 374(2):371-377

37. Mamelak D, Lingwood C (2001) The ATPase domain of Hsp70 possesses a unique binding specificity for 3'-sulfogalactolipids. J Biol Chem 276(1):449-456

38. Whetstone H, Lingwood C (2003) 3'Sulfogalactolipid binding specifically inhibits Hsp70 ATPase activity in vitro. Biochemistry 42(6):1611-1617

39. Lipinski CA, Lombardo F, Dominy BW, Feeney PJ (1997) Experimental and computational approaches to estimate solubility and permeability in drug discovery and development settings. Adv Drug Deliv Rev 23(1-3):3-25

40. Chene P (2002) ATPases as drug targets: learning from their structure. Nat Rev Drug Discov 1(9):665-673

41. Halgren TA (2009) Identifying and characterizing binding sites and assessing druggability. J Chem Inf Model 49:377-389

42. Fersht AR (1987) The hydrogen bond in molecular recognition. Trends Biochem Sci 12:301-304

43. Veber DF, Johnson SR, Cheng HY, Smith BR, Ward KW, Kopple KD (2002) Molecular properties that influence the oral bioavailability of drug candidates. J Med Chem 45(12):26152623 